\title{
Introduction: The International Diffusion of Liberalism
}

\section{Citation}

Simmons, Beth A., Frank Dobbin, and Geoffrey Garrett. 2006. Introduction: the international diffusion of liberalism. International Organization 60, no. 4: 781-810.

\section{Published Version}

http://dx.doi.org/10.1017/S0020818306060267

\section{Permanent link}

http://nrs.harvard.edu/urn-3:HUL.InstRepos:3119447

\section{Terms of Use}

This article was downloaded from Harvard University's DASH repository, and is made available under the terms and conditions applicable to Other Posted Material, as set forth at http:// nrs.harvard.edu/urn-3:HUL.InstRepos:dash.current.terms-of-use\#LAA

\section{Share Your Story}

The Harvard community has made this article openly available.

Please share how this access benefits you. Submit a story.

\section{Accessibility}




\title{
Introduction: The International Diffusion of Liberalism
}

\author{
Beth A. Simmons, Frank Dobbin, \\ and Geoffrey Garrett
}

\begin{abstract}
Political scientists, sociologists, and economists have all sought to analyze the spread of economic and political liberalism across countries in recent decades. This article documents this diffusion of liberal policies and politics and proposes four distinct theories to explain how the prior choices of some countries and international actors affect the subsequent behavior of others: coercion, competition, learning, and emulation. These theories are explored empirically in the symposium articles that follow. The goal of the symposium is to bring quite different and often isolated schools of thought into contact and communication with one another, and to define common metrics by which we can judge the utility of the contending approaches to diffusion across different policy domains.
\end{abstract}

The worldwide spread of economic and political liberalism was the defining feature of the late twentieth century. Free-market-oriented economic reformsmacroeconomic stabilization, liberalization of foreign economic policies, privatization, and deregulation - took root in many parts of the world. At more or less the same time, a "third wave" of democratization and liberal constitutionalism washed over much of the globe. Most economists believe the gains to developing countries from the liberalization of economic policies to be in the hundreds of billions of dollars. But they also acknowledge the instability and human insecurity sometimes left in liberalization's wake. ${ }^{1}$ Political scientists argue that the rise of democracy has contributed to the betterment of both human rights and international security. ${ }^{2}$ While the precise effects of these twin waves of liberalization are still debated, it is hard to deny that they have had a tremendous impact on the

For helpful comments on an earlier draft of this article, the authors wish to thank Barry Eichengreen, Lisa Martin, and John Meyer. Nancy Brune and Alexander Noonan provided excellent research assistance. The authors also wish to acknowledge and thank the Yale Center for International and Area Studies, the UCLA International Institute, and the Weatherhead Center for International Affairs at Harvard University for funding conferences at which this collection of symposium papers were discussed.

1. See Dobson and Hufbauer 2001; Kaplinsky 2001; and Prasad et al. 2003.

2. Doyle 1986. 
contemporary world. But we are interested in a prior question: why has much of the world come to accept markets and democracy?

Some commentators focus on the exercise of American power. According to this line of argument, the hegemonic United States-often acting through the Bretton Woods international economic institutions it helped create after World War II-has used a combination of carrots (political and military support, as well as preferential access to U.S. markets) and sticks (from strings attached to financial assistance to threats of military coercion) to impose its vision for political and economic liberalism on the rest of the world. Others see the decentralized process of technologically induced globalization at work. Sharp declines in the ability of governments to control cross-border movements of goods, services, and capital are thought to have forced countries to compete with each other for investment and market share by enacting political and economic reforms that reduce governmental constraints on finance and firms. Still another line of argument focuses more on the emergence of influential ideologies, from monetarism to glasnost, which may have little to do with political power or market dynamics.

This symposium puts these processes under the analytic microscope. We are interested primarily in how a given country's policy choices are affected by the prior choices of other countries, sometimes mediated by international organizations and private transnational actors. There is considerable variation in the spread of liberal policies across time and space, which the contributors to this symposium exploit to explore the processes underpinning liberalization. Our principal objective is to shed light on the causal mechanisms that explain the timing and geographic reach of liberal innovations. What has caused these new policies to diffuse across time and space?

The contending approaches to liberalization we outline share the assumption that national policy choices are interdependent-that governments adopt new policies not in isolation but in response to what their counterparts in other countries are doing. In this introduction, we review four distinct mechanisms through which interdependent decision making may take place-coercion, competition, learning, and emulation. We begin by describing the patterns of liberalization that we seek to explain. We then move on to distinguish interdependent decision making by national governments from the null hypothesis of independent decision making, which has been for decades the workhorse approach in comparative and international political economy. We then elaborate the four classes of diffusion hypotheses found in the literature, which are subsequently tested alongside one another and developed in the other articles in this symposium. We end by previewing the findings of the coming articles.

\section{The Spread of Economic and Political Liberalism}

We define liberalism conventionally. Economic liberalism, in the classic rather than the American sense, refers to policies that reduce government constraints on eco- 


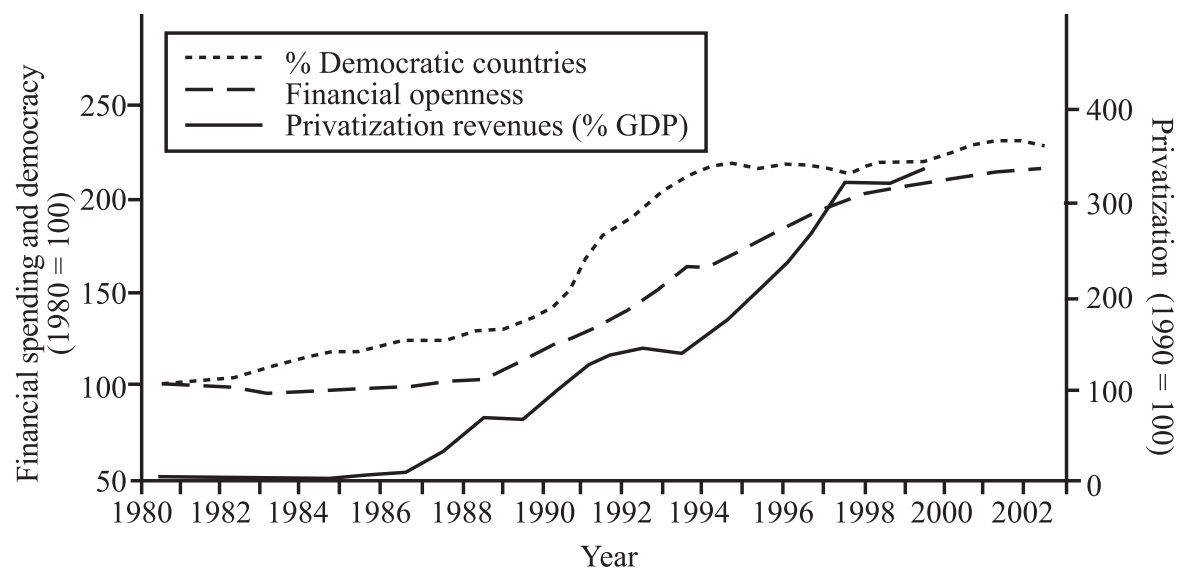

FIGURE 1. Political and economic liberalization around the world

nomic behavior and thereby promote economic exchange: "marketization." Political liberalism refers to policies that reduce government constraints on political behavior, promote free political exchange, and establish rights to political participation: "democratization."

There is no doubt that both forces have been powerful facets of the global political economy in recent decades. Figure 1 documents this trend on three key indicators of liberalization in the 1980s and 1990s. The privatization of state-owned enterprises went from an iconoclastic policy idea in Margaret Thatcher's 1979 British election manifesto to a major element of economic policy in both developed and developing countries over the course of twenty years. ${ }^{3}$ At more or less the same time, there was a dramatic opening of national economies to external forcesexemplified by substantial reductions in policy restrictions on cross-border capital flows. ${ }^{4}$

But the scope of liberalization was not limited to economic policy. Perhaps the headline political statistic of the late twentieth century was that the proportion of democratic countries in the world more than doubled between 1980 and 2000, from under 30 percent to almost 60 percent (while the number of sovereign states in the world also doubled to roughly 200). ${ }^{5}$

Moreover, all three curves in Figure 1 follow the classic S-shaped logistic curve associated with the diffusion of innovation, beginning with hesitant early moves to liberalize in only a few countries, followed by a rapid escalation in the trend, and finally a leveling off. In less than a generation, a new equilibrium level of liberalism appears to have been established in each realm.

3. Brune et al. 2004.

4. Simmons and Elkins 2004.

5. Przeworski et al. 2000. 


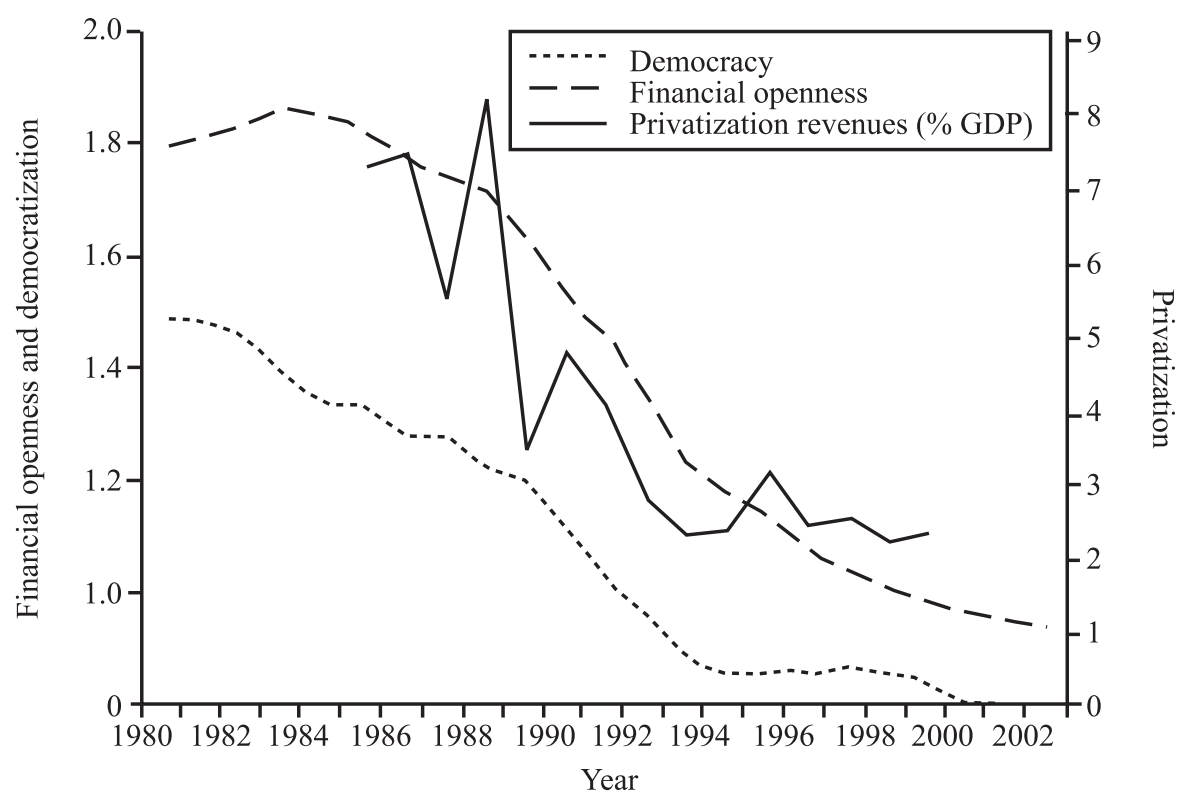

FIGURE 2. Variations in liberalization around the world (SD/mean)

Figure 2 demonstrates that in addition to this broad trend toward political and economic liberalism, there was considerable convergence in national trajectories. ${ }^{6}$ Cross-national variation, defined in terms of coefficients of variation (the standard deviation of each distribution divided by its mean), declined substantially in each of the three areas of privatization (representing domestic economic liberalization), capital account openness (external economic liberalization) and democracy (political liberalization).

It is important to note, however, that these broad global trends toward liberalism belie substantial variations in the paths pursued by countries in different parts of the world. Figures 3 to 5 break down the global averages presented in Figure 1 by geographic region. As students of democracy know well, there have been three waves of democratization in recent decades (see Figure 3). Latin American countries began to democratize in the 1970s, to the point where today the region is almost as democratic as North America and Western Europe. The same kind of pattern, though less pronounced, was apparent in East Asia and the Pacific. A second wave of democratization centered around the fall of the Berlin Wall and the subsequent velvet revolutions in the former Soviet bloc between 1989 and 1991but it should also be noted that the pace and extent of democratization was almost

6. For recent reviews of the "convergence" literature, see Heichel, Pape, and Sommerer 2005; and Knill 2005. 

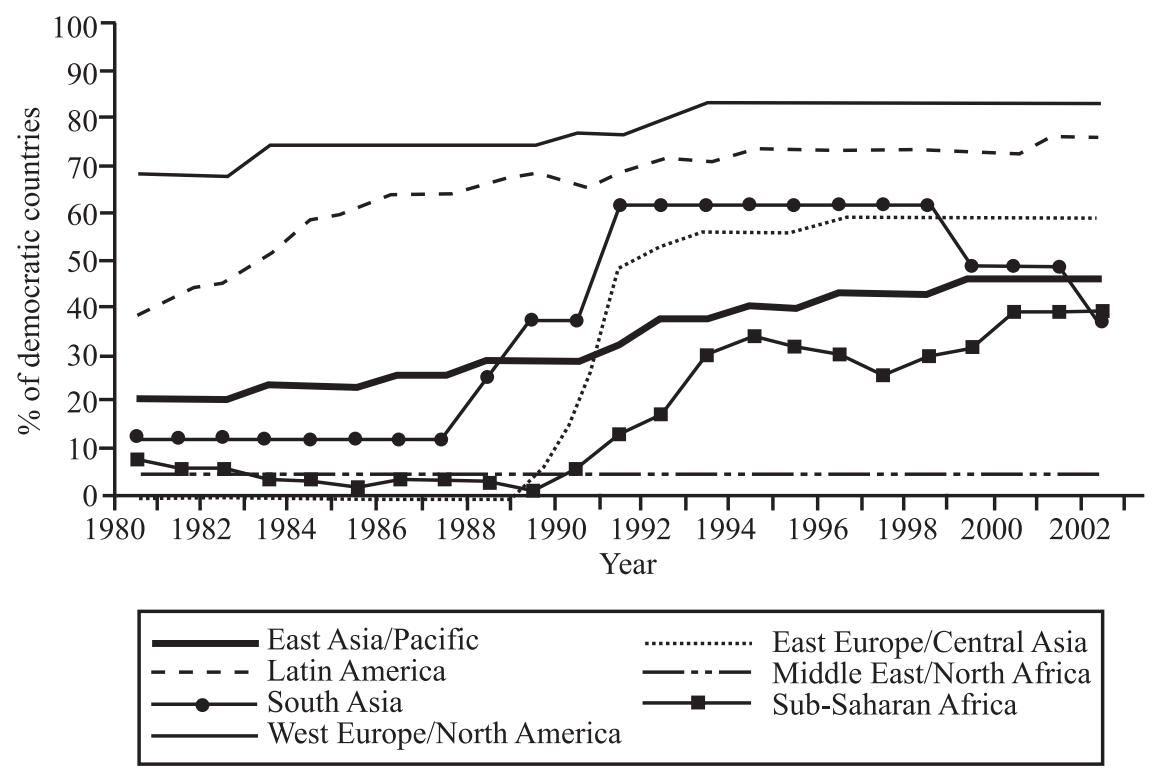

FIGURE 3. Regional variations in democracy

as great, and began just a few years earlier, in South Asia. The number of democracies in Sub-Saharan Africa also began to increase in 1989, though that region still lags behind Eastern Europe and Central Asia. The Middle East and North Africa saw no significant democratization in the 1980s and 1990s.

Figure 4 presents data on the openness of national economies to international financial flows with respect to foreign direct investment (FDI); the buying and selling of stocks, bonds and currencies across national borders; and international bank lending. The most dramatic feature of this figure is the rapid march among the countries of North America and Western Europe toward complete financial openness. The same general trend, though muted, applies in Central Europe, East Asia, and Latin America. There were small moves toward capital mobility in SubSaharan Africa, but only in the mid- and late 1990s. Financial policy remained relatively closed in the Middle East and in South Asia in the 1980s and 1990s.

Finally, Figure 5 presents data on regional variations in privatization. Given that the data are measured in terms of the prices at which state-owned assets were sold (relative to gross domestic product [GDP]), it is not surprising that these curves are less smooth. Nonetheless, it is clear that privatization took off earlier and was more pronounced in Eastern Europe and Central Asia, Latin America and North America, and Western Europe than elsewhere. The radical and thoroughgoing nature of the velvet revolutions in the former Soviet countries is readily apparent in the case of privatization, no doubt in large measure because these countries had the most state-owned assets to sell in the 1990s. 

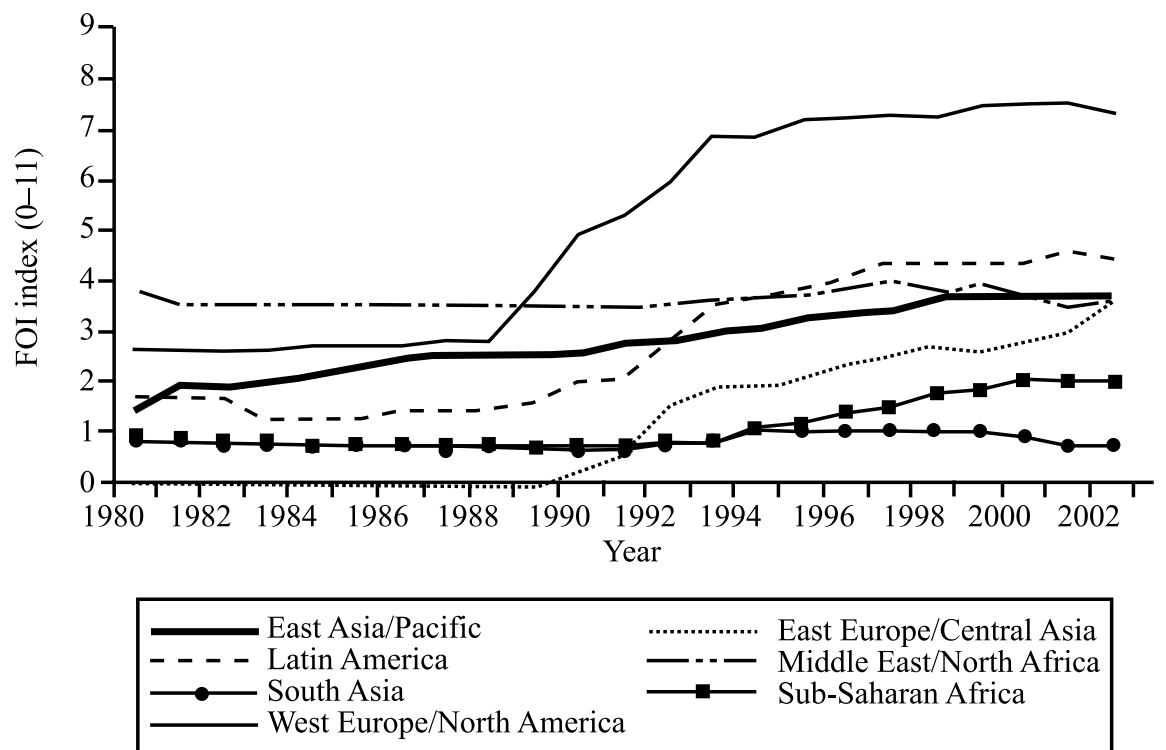

FIGURE 4. Regional variations in financial openness
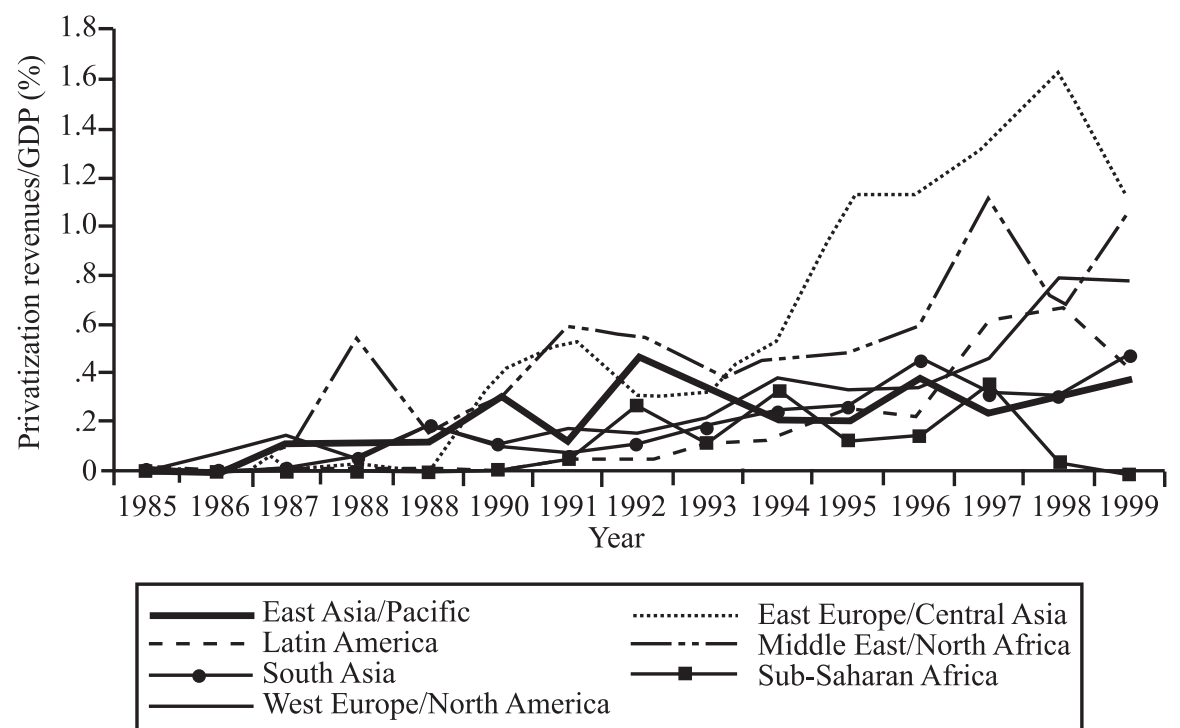

FIGURE 5. Regional variations in privatization 
Figures 3 to 5 demonstrate that despite the global trend toward liberalism, there were important differences in the trajectories of different parts of the worlddifferences across regions, over time, and among different dimensions of liberalization. The Middle East and North Africa did not liberalize much, if any, in the 1980s and 1990s. Latin America democratized and marketized gradually over the whole period, whereas the shift from state socialism to capitalist democracy was much more abrupt in Eastern Europe.

What kinds of dynamics produced these "regional effects"? Growing literatures in political science and sociology point to different explanations for such policy clustering, which we dub "diffusion." We now define diffusion and distinguish it from alternative causal forces.

\section{Policy Diffusion - and Its Alternatives}

International policy diffusion occurs when government policy decisions in a given country are systematically conditioned by prior policy choices made in other countries (sometimes mediated by the behavior of international organizations or even private actors or organizations). Theories of diffusion have pointed to diverse mechanisms ranging from Bayesian learning to rational competition through hegemonic domination to unthinking emulation of leaders. Theories of diffusion encompass a wide array of assumptions about who the primary actors are, what motivates their behavior, the nature and extent of the information on which they base decisions, and their ultimate goals.

But what theorists of diffusion explicitly reject is the notion that processes of policy change can adequately be understood by conceiving of national governments as making decisions independently of each other. Policy independence is thus the null hypothesis that motivates our project. ${ }^{7}$ Most cross-national social science research focuses on variants of this null hypothesis, developing explanations based on the specific conditions governments encounter. For example, differences in economic development, ${ }^{8}$ social cleavages, ${ }^{9}$ national institutions, ${ }^{10}$ and elite interactions ${ }^{11}$ have all been argued to play important roles in democratization. Students of the spread of democracy, and of market institutions, frequently presume that decisions to democratize are made in isolation.

A small literature has developed that takes seriously the international diffusion of democracy, ${ }^{12}$ but little has been done to date to fashion an integrated model or to test competing hypotheses. The political economy literature, perhaps more sur-

7. Compare, for example, Lenschow, Liefferink, and Veenman 2005.

8. Przeworski et al. 2000.

9. Collier 1999.

10. Linz and Stepan 1996.

11. O'Donnell, Schmitter, and Whitehead 1986.

12. See Huntington 1991; Markoff 1996; O'Loughlin et al. 1998; and Starr 1991. 
prisingly, is also dominated by research that assumes independent policy choice. Political economists have analyzed restrictions on cross-border capital flows as tools of economic repression ${ }^{13}$ or reasoned that such controls could be explained by partisanship, domestic cleavages and governments' desires for seigniorage. ${ }^{14}$ Recent work on the choice of monetary and exchange-rate institutions also focuses on the null hypothesis, as amply demonstrated by a recent special symposium of International Organization focusing on domestic political pressures, ${ }^{15}$ domestic veto players, ${ }^{16}$ federalism, ${ }^{17}$ coalition governments, ${ }^{18}$ and domestic policy transparency ${ }^{19}$ as determinants of national monetary institutions and policies.

In the past twenty years, an important strand of research in political economy has linked domestic policy choice with constraints, pressures, and opportunities generated by the international economy. Gourevitch studied the impact of position in the international economy on domestic responses to economic crisis. ${ }^{20}$ Rogowski analyzed trade policy coalitions in comparative advantage terms. ${ }^{21}$ Frieden hypothesized that the preferences of domestic groups vis-à-vis financial liberalization and exchange-rate policy were the function of their specific endowments. ${ }^{22}$ But these studies tend to reduce "external influences" to simple exogenous factors, notably changes in relative prices around the world. ${ }^{23}$ None explicitly explores the possibility of interdependent decision making - the impact of policy choices in other countries on the behavior of governments at home.

Frieden and Rogowski posited the simplest possible argument to explain economic liberalization in recent decades. They contend that "exogenous easing," such as declining transport and communication costs, has greatly increased the opportunity costs of closure. ${ }^{24}$ Over time, these costs have mounted on governments, increasing the incentive to open their economies. As Garrett and Lange were quick to note, however, the pace and extent of liberalization have varied substantially across countries. ${ }^{25}$ Garrett and Lange argued that it was critical to take seriously this variation, rather than dismissing it as "noise," as theorists of exogenous easing tended to do. They then proposed a framework for analyzing how constellations of domestic interests and institutions mediate between lower costs of international movements and national policy liberalization.

13. Giovannini and De Melo 1993.

14. See Epstein and Schor 1992; Grilli and Milesi-Ferretti 1995; and Quinn and Inclán 1997.

15. Clark 2002.

16. Keefer and Stasavage 2002.

17. Hallerberg 2002.

18. Bernhard and Leblang 2002.

19. Broz 2002.

20. Gourevitch 1986.

21. Rogowski 1989.

22. Frieden 1991.

23. Keohane and Milner 1996.

24. Frieden and Rogowski 1996.

25. Garrett and Lange 1995. 
Our intention is not to deny that relative prices and other factors exogenous to the decision-making environment in any one country affect policy choice. But from our perspective, the critical analytic point is that exogenous shocks-such as changing world prices-are a commonly experienced phenomenon to which governments must decide how to respond. Their responses are no doubt influenced in a "bottom-up" fashion by conditions and institutions within their countries. ${ }^{26}$ But they are surely also affected by the decisions and behavior of other countries. The challenge facing theorists of international policy diffusion is to demonstrate that domestic political and economic factors cannot alone predict when governments adopt new policies, and to develop and test hypotheses that distinguish among the several possible mechanisms of diffusion. We argue that government decision making in these critical areas has in fact been highly interdependent and that the mechanisms of diffusion can potentially be teased out in empirical analyses.

\section{Mechanisms of Global Diffusion}

Interdependent decision making has long informed the study of international relations and international political economy. There is an affinity between the recent game theory revolution in the social sciences and international policy diffusion. ${ }^{27}$ But diffusion processes are characteristically uncoordinated processes ${ }^{28}$ which cannot easily be subsumed under the umbrella of fully informed, rational decision making. Indeed, the interest of the social sciences in diffusion is not only much broader; it also long predates the influence of game theory. Anthropologists in the first half of the twentieth century "laid primary stress on diffusion, that is, the process of adopting or borrowing by one culture from another various devices, implements, institutions, and beliefs." ${ }^{29}$ More recently, sociologists have argued that nations mimic their successful peers almost ritualistically. ${ }^{30}$ Economists debate whether there is a rational/material base to international financial crises, or whether they result from "contagious" herd behavior. ${ }^{31}$ Political scientists have incorporated the diffusion of ideas into their accounts of the choice of economic policies. ${ }^{32}$ Students of organizational behavior model international networks among people and firms that are said to drive the diffusion of technology and management practices. ${ }^{33}$

26. See, for example, Gilardi's study of the diffusion of independent regulatory agencies (2005).

27. Lake and Powell 1999.

28. Elkins and Simmons 2005.

29. Malinowski 1944, iii., 17.

30. Thomas et al. 1987.

31. Kaminsky and Reinhart 2000.

32. See Hall 1989; and McNamara 1998.

33. See Goolsbee and Klenow 1999; Keller 2002; and Powell 1990. 
But which of these processes is the most important, and under what circumstances does each operate? How can we distinguish among them, both theoretically and empirically? Next we sketch four discrete diffusion mechanisms that are amenable to rigorous empirical testing.

\section{Coercion}

One prominent explanation for the spread of economic and political liberalism involves a distinctly antiliberal mechanism: coercion. Powerful countries can explicitly or implicitly influence the probability that weaker nations adopt the policy they prefer by manipulating the opportunities and constraints encountered by target countries, either directly or through the international and nongovernmental organizations (NGOs) they influence. Whether direct or mediated, this mechanism may involve the threat or use of physical force, the manipulation of economic costs and benefits, and/or even the monopolization of information or expertise-all with the aim of influencing policy change in other countries. Coercive diffusion involves power asymmetries that the strong exploit to impose their policy preferences on weaker countries. ${ }^{34}$

Coercion theorists begin by assuming that a powerful nation has an intentional motive to stimulate policy change in another country or countries. Most also assume that weaker countries would prefer to resist were it not for the foreign influence. ${ }^{35}$ The capacity and will of the more powerful player to influence the incentives (broadly understood) of the weaker to liberalize are key to the "hard" coercion approach. In the simplest form of this theory, dominant nations and their agents directly coerce weaker nations to adopt policy changes that those weaker nations would not otherwise have adopted.

There are many variations on this basic theme. Dominant countries may exercise power bilaterally ${ }^{36}$ or through collective entities acting as their allies or agents. ${ }^{37}$ In some areas, private actors may play important roles in coercion. ${ }^{38}$

34. Essentially hierarchical in nature, coercion is a form of "vertical diffusion" discussed in much of the literature on federalism and European regionalism. See, for example, Daley and Garand 2005; and Gilardi 2005.

35. This is not always easy to establish empirically, even in cases where it is broadly assumed that governments are being coerced. Vreeland 2003, for example, argues that governments often accept IMF loans because they want conditions externally imposed on them, rather than the other way around. See Drazen 2002, for a similar argument.

36. The United States, for example, is putting significant bilateral pressures for policy liberalization on the would-be members of the Central American Free Trade Agreement; see Financial Times, 17 December 2003, The Americas, 2. On the Mexico-European Union Political and Economic Association Agreement of December 1997, which ultimately led to a free-trade agreement in March 2000, see Sanahuja 2000. The European Commission and the United States have demanded privatization in developing countries in exchange for further agricultural liberalization. See "A privatisers' hit list: European commission demands to deregulate services spell disaster for the developing world," The Guardian (London), 18 April 2002.

37. The IMF and the World Bank, along with various US government agencies, are seen as exemplars of coercive liberalization, through various forms of conditional lending and other assistance. On the "Washington consensus", see Williamson 1993.

38. Private banks, for example, in IMF conditionality. See Gould 2003; and Edwards 1997. 
While the identity of the actors may differ, their relationship is characteristically hierarchical: the more powerful actors have access to, and potentially use, resources to affect the incentives of others to liberalize. Hard coercion of course has its limits. The more resistant the weaker party, the greater the incentives required and the more serious the "enforcement" and "monitoring" costs needed to secure the desired policy change. ${ }^{39}$

Various forms of "soft" coercion may be common in the diffusion of policy liberalization. The policies of powerful governments often constitute focal points in policy coordination games with multiple equilibria. ${ }^{40}$ Dominant countries adopt one policy approach - for example, the Basel Accord in capital market regulationthat establishes the equilibrium in which weaker countries are expected to participate. ${ }^{41}$ Coercive intent may or may not be at work in such cases. It is only a small step to Gruber's notion of "go-it-alone-power," by which larger countries make policy decisions that significantly alter the status quo for others, giving the latter little choice but to follow suit. ${ }^{42}$

Softer still, powerful countries may be closely aligned with theories, information, or ideas that favor particular policy moves, such as liberalization. With a sort of Gramscian ideological hegemony, dominant actors can influence others through ideational channels without exerting physical power or materially altering costs or benefits. By virtue of their central positions in policy networks, more powerful countries may be influential in the framing of policy discussions. ${ }^{43}$

How can one demonstrate that coercion (in its harder and softer manifestations) actually explains policy change? In order to make the case, one must identify the coercive actors, show that these actors support the policy in question, and demonstrate the channel through which the powerful influence policy change across borders. If the International Monetary Fund (IMF) is the hypothesized source of influence (acting as a de facto agent of the leading nations that influence the organization), empirical tests should demonstrate that the IMF favored the policy in question and that countries adopting the policy were particularly dependent on IMF largesse. Similarly, studies linking policy diffusion to soft coercion should show that the policy ideas actively promoted by strong countries are more likely to be put into practice in weaker countries structurally or situationally dependent on them.

39. See Eichengreen and Ruehl 2000; Sachs and Huizinga 1987; and Cordella and Dell'Ariccia 2002.

40. See, generally, Schelling 1960. Garrett and Weingast 1993 demonstrate the importance of Germany as a focal point in the European Union.

41. Simmons 2001.

42. Gruber 2000 provides the example of Mexican liberalization in the wake of the US-Canada Free Trade Area.

43. Hira 1998. Practically every international financial institution-from the Bank for International Settlements to the International Monetary Fund to the various regional institutions-has a research department engaged in the dissemination of economic models favored by economists in wealthy, core countries. See de Vries 1997; and Polak 1997. 


\section{Competition}

Competition is a more decentralized mechanism for policy diffusion than coercion. Theorists of competition-based diffusion stress the differential attractiveness of certain policies to investors and buyers in international markets. Competition arguments are typically applied to economic policies, though there is some evidence that investors and even buyers in the global marketplace have preferences for certain political systems, sometimes for liberal democracy and sometimes for benevolent authoritarianism. ${ }^{44}$ Students of competitive diffusion elaborate the policy moves through which governments compete with each other for internationally mobile capital and export-market share. Simplifying regulatory requirements, ameliorating investment risks, and reducing tax burdens are often viewed as policy choices that can, quite quickly, make an investment locale more attractive, exports more competitive, and an economy more vital. The mechanisms underlying competitive diffusion are broadly the same for theorists who see competition as a positive force promoting efficient policy tools and those who see competition producing a "race to the bottom" as countries slash taxes, social spending, and environmental and labor regulations to win over investors and export markets.

Competitive theories of the diffusion of liberalization must stipulate why competition among countries, and not just "efficiency" within them, drives the spread of a particular policy. After all, economic efficiency is likely to be an important element in the decision calculus of governments. The question is: how and why might competition among countries elicit a particular policy change? The conventional wisdom is that in the absence of competition, governments often prefer extensive market regulation and large public economies, which can help them to achieve economic stability, pursue social purposes such as the redistribution of wealth and risk, and collect rents. As long as competing jurisdictions have similar levels of regulation and public investment, the thinking goes, those controlling mobile factors of production can choose along locations on these dimensions. This is how a high regulation equilibrium can be sustained.

The high regulation equilibrium may be destabilized, however, once a government from a competing jurisdiction breaks ranks and begins to liberalize, regardless of the reason. When a country's policy choice gives it an edge in attracting foreign investment or in selling to export markets, competitors will have strong incentives to give up policy tools they favor on political or social grounds and follow suit-for fear of large-scale losses of investment and jobs. This of course happens whether the new policy actually creates favorable circumstances, or whether investors and global buyers merely believe that it creates favorable circumstances.

Competition theorists share some important assumptions. First, they assume that the policy under examination has the potential to affect the flow of international production and capital or the attractiveness of a nation's exports. Absent this 
assumption, there would be no reason to respond to the policies of another government; nothing tangible would be at stake.

Second, they assume that the policies that diffuse have consequential effects in the short- to medium term. The longer it takes for a specific policy to affect international business activity, the less likely a government will be to give up a favored policy tool. Governments, after all, do not have infinite time horizons.

Third, competitive models assume an information-rich (in fact, close to perfect) environment. Competitive models of diffusion assume that it is possible for governments (and analysts) to determine which countries compete with each other, in which markets, and how intense the competition is. Governments are also assumed to know how policy changes in other countries will affect the global economic landscape and how this will in turn affect welfare in their own countries. Diffusion by competition is expected to increase the more intense the economic competition between countries and the more a given policy instrument is expected to influence that competition.

Finally, whereas coercion theorists assume that the most important relationships in diffusion processes are vertical, competition theorists assume that the most important relationships are horizontal. The policies of one's economic equals are more important than the policies of the economic powers. Policy liberalization should spread most readily among units that are similar on important competitive dimensions, among the Davids and among the Goliaths but not necessarily from the Goliaths to the Davids of the world.

That jurisdictions compete in their formulation of economic policies is hardly a new insight. This dynamic has been documented extensively at the subnational level, ${ }^{45}$ with respect to a wide range of phenomena ranging from tax concessions to the introduction of lotteries. ${ }^{46}$ Competitive models are increasingly employed in studies of regional integration, for example in the context of the European Union. ${ }^{47}$ Several influential studies argue that competition for mobile capital has driven macroeconomic "convergence" around the neoliberal ideal, first in the Organization for Economic Cooperation and Development (OECD) and then in the developing world as well, due to competition among countries for increasingly mobile capital and firms-reducing social programs ${ }^{48}$ and shifting the tax burden from capital to labor. ${ }^{49}$

Unfortunately, however, most studies of global competition do not test the theory directly but assume that indicators of "openness" suffice to capture the pressures

45. See Cai and Treisman 2004; and Gray 1994.

46. See Berry and Berry 1990; Brueckner 2000; and Peterson and Rom 1990.

47. See, for example, Sinn and Ochel 2003.

48. See Garrett 1998; Garrett and Mitchell 2001; Garrett 2001; Kaufman and Segura-Ubiergo 2001; and Rudra 2002. The evidence for a race to the bottom in social spending under conditions of greater openness in these studies is decidedly mixed.

49. See Genschel 2002; Rodrik 1997; and Oates 2001. After a decade of careful research, however, the empirical evidence on whether international market exposure has made taxes more regressive remains inconclusive. See Baldwin and Krugman 2004; Garrett and Mitchell 2001; and Swank 1992 and 1998. 
governments experience to alter their fiscal or social policies. ${ }^{50}$ A more precise test of the competition hypothesis involves linking liberalization in country A to the policies of A's competitors in the world economy. ${ }^{51}$ There is no particular reason to believe that A's level of exposure to world markets per se is responsible for policy liberalization or deregulation, especially if few other countries with whom A competes have themselves done so.

Competition models should specify as precisely as possible the areas in which governments can be expected to be sensitive to the policies of their peers. Exporters, for example, are likely to be most influenced by policy changes in other countries that affect input costs, such as wages. A policy that reduces labor costs in a competitor country should lead domestic exporters to lobby their government for an "equal playing field." Foreign direct investors are sensitive to a range of transaction costs flowing from the political risks and contractual hazards inherent in operating a firm in a foreign jurisdiction. ${ }^{52}$ Policies that reduce these transaction costs in nations that compete for foreign investments should stimulate similar innovation at home. ${ }^{53}$ Foreign portfolio investors are especially responsive to taxes, ${ }^{54}$ inflationary pressures, ${ }^{55}$ and capital controls. ${ }^{56}$ These are all areas in which we would expect diffusion by competition to be especially powerful.

Competitive diffusion should be more pronounced among countries located within the same competitive networks. That is, one might expect a country to be much more influenced by the policy choices of its trading partners, countries with which it competes for trade in third countries, and countries with similar export profiles, than by the policies of countries that are not part of its commercial network. Competition for capital is harder to measure because networks may be more latent than those revealed in trade patterns. Competition for FDI could be a function of the degree to which countries share the same export partners, or the extent to which countries send the same kinds of products abroad. The more similar two countries are on these dimensions, the more competitive for FDI they are likely to be and the greater the weight of country A's policy in predicting country B's. ${ }^{57}$ For policies expected to affect nonequity portfolio investment, countries with similar credit ratings might be the most direct competitors. ${ }^{58}$

In sum, the empirical task facing the competition approach to international policy diffusion is twofold. First, one must identify the network(s) of countries that

50. See, for example, Neumayer and de Soysa's 2006 fine test of liberalization's effect on labor standards and practices.

51. Spatial models measuring the "distance" between two competitors are an especially promising way to proceed empirically. Such spatial models are explained in a recent article by Beck, Gleditsch, and Beardsley 2006.

52. Henisz 2000.

53. See Elkins, Guzman, and Simmons 2006.

54. Gastanaga, Nugent, and Pashamova 1998.

55. Mosley 2003.

56. Simmons and Elkins 2004.

57. See, for example, Elkins, Guzman, and Simmons 2006.

58. Simmons and Elkins 2004. 
compete in different markets. Second, proponents must demonstrate that changes in the policies of the members of a competitive network increase the probability of similar changes in other countries in the network-with the pace and probability of change an increasing function of "proximity" in the network (measured by similarities in trade profiles, per capita income, and so on).

\section{Learning}

Learning refers to a change in beliefs or change in one's confidence in existing beliefs, which can result from exposure to new evidence, theories, or behavioral repertoires. ${ }^{59}$ Some researchers distinguish "simple learning," in which new information leads to changes in means but not ends, from more complex cognitive processes involving new beliefs about ends as well. In the realm of public policy, actors may be learning at both the simple tactical level (how to better achieve a particular goal) and at a deeper level (what goals they should pursue). ${ }^{60}$ For diffusion theories based on learning, the choices of others are important not because they affect the payoffs of a policy choice (as in both hegemonic and competitive theories discussed above), but rather because others' choices generate new data that informs beliefs about causal relationships. ${ }^{61}$

Three approaches have been useful in understanding social learning: political science perspectives on social knowledge; Bayesian learning from economics, and the work on channeled learning developed largely by sociologists. In political science, Haas's work has drawn attention to the generation of social knowledge, or "the sum of technical information and of theories about that information which commands sufficient consensus at a given time among interested actors to serve as a guide to public policy designed to achieve some social goal." ${ }^{\prime 2}$ In this approach, policy innovation spreads in the wake of the diffusion of a shared fund of (often technical) knowledge among elites about what is effective. Learning in this literature is fostered by a cluster of intersubjectively defined conditions: shared norms, beliefs, and notions of evidentiary validity. ${ }^{63}$ "Epistemic communities" are major actors in the development of social knowledge and are especially influential in the policymaking process. This approach has much in common with constructivism, which we discuss under "emulation" below.

Economists take a more objectivist and individualistic view. They focus on the process of Bayesian updating, in which individuals add new data to prior knowl-

59. See the very useful review of the learning literature, especially as it has been applied to foreign policy decision making, by Levy 1994.

60. Philip Tetlock, for example, argues that learning can be hierarchical, but that most foreign policy learning takes place at the tactical level: political decision makers reconsider their basic strategic assumptions and orientation only after repeated failures to generate a tactical solution. See Levy 1994, 286.

61. Elkins and Simmons 2005.

62. Haas 1980, 367-68.

63. Haas 1992. 
edge and beliefs to revise their behavior accordingly. With new information, the probable range of hypotheses that might explain those data is likely to shift and also to narrow. The more consistent the new data, the more likely an actor's probability estimates of the truth of various hypotheses are to converge on a narrow range of possibilities - and ultimately policies. Figure 6 illustrates the basic Bayesian mechanism. The flattest curve represents an actor's initial estimate of which of several possible relationships is true. The wide dispersion indicates a good deal of uncertainty, but Hypothesis D is initially viewed as most likely. New data allow for a revision of the probability that $\mathrm{D}$ is true. In this case, the first round of new data causes the actor to believe that $\mathrm{D}$ and $\mathrm{C}$ are equally probable. Another round of observed data solidifies the belief in the probability of $\mathrm{C}$. Bayesian learning has the effect of shifting both the mean and the dispersion of beliefs about the true nature of relationships in the world. In Figure 6, additional information shifted actors' beliefs in hypothesis D toward hypothesis C. At the same time, certainty about this assessment solidified in the face of new information.

It is important to note, however, that nothing in the Bayesian learning mechanism guarantees that actors will converge on "the truth." The process merely

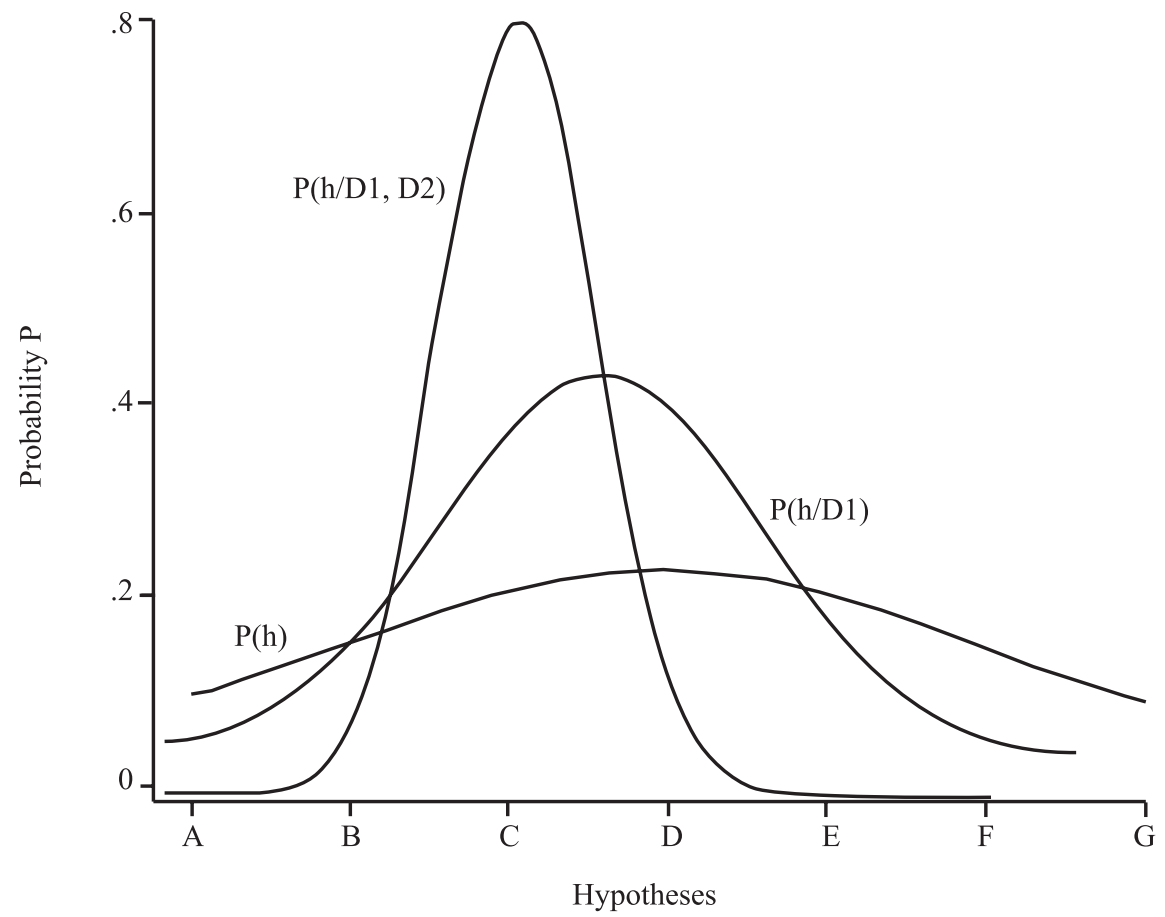

Note: The figure represents changes in the estimated probability that hypotheses A through G are correct given new data or information (D1 and D2). 
describes the way in which new information affects actors' probability assessments. Just as an individual can "learn" a theory in physics that is later disproven, nations can take the wrong lessons from the policy experiences of others or can learn a wrong-headed theory. Exactly what actors learn will be influenced by a number of factors, including the source of new information and how it is processed.

Bayesian learning is a "rational" process in the sense that actors are assumed to make optimal use of available information-weighting learning in terms of objective similarities among cases (countries), extracting the right signal from the mass of noise, and so on. However, the aggregation of these individual choices may not be socially optimal. Economists recognize that sequential social learning can be responsible for "herd behavior," as was evident in successive international financial crises in the 1990s. More generally, models in which actors learn from the decisions of a small number of leaders and suppress their private information tend to lead to Pareto-inefficient outcomes. ${ }^{64}$

One of the central issues in any learning model is how "data" are gathered and interpreted. Where do new data D1 and D2 in Figure 6 come from? It is obviously impossible for any actor to collect and process all information that might bear on a particular set of hypotheses. Information is costly, and actors are faced with a sampling problem. March and Simon argued long ago that the rationality of individual decision makers is bounded by their capacity to assemble and evaluate relevant evidence of the efficacy of a policy approach. ${ }^{65}$ Policymakers may use cognitive shortcuts in which attention is drawn to highly successful countries or to highly successful outcomes, rather than assessing all available information as the Bayesian approach demands. This kind of channeled learning may be facilitated by communication networks among actors who already are connected in other ways. The type of exchange of information is central to many sociological studies of policy diffusion. ${ }^{66}$ In these models, the cognitive process is dominated by an "availability heuristic," in which actors unable to retrieve a full sample of information base their decisions on only those instances that are available to themlimiting the viable range of policy alternatives. ${ }^{67}$

Several important studies indicate the importance of learning within communications networks in the policy arena. ${ }^{68}$ Gray's pioneering work on policy innovation among the states of the United States, for example, demonstrated that the intensity of contact among officials was associated with policy diffusion. ${ }^{69}$ Recent research on how developing countries formulate and implement policies ranging

64. See Banerjee 1992; and Bikhchandani, Hirshleifer, and Welch 1992.

65. March and Simon 1993.

66. See Coleman et al. 1966; and Rogers 1995.

67. See Kahneman, Slovic, and Tversky 1982; Gale and Kariv 2003; and Axelrod 1997.

68. The international relations literature has recognized a role for channeled learning outside of the policy realm. For example, with respect to coup contagion, see Li and Thompson 1975.

69. See Gray 1973. See also Lutz 1987. 
from pension reform to exchange-rate regimes to privatization programs similarly points to strong social learning from neighbors. ${ }^{70}$ It is well documented in the international literature that the process of negotiating and maintaining institutional affiliations may create opportunities to learn and persuade. ${ }^{71}$ International institutions are another natural conduit for learning and, especially, for organized pedagogy. The IMF, for example, regards its research function as a way to disseminate the lessons of earlier liberalizers (usually developed countries) to the rest of the world (primarily the developing countries).$^{72}$ Many other examples can be found in the literature. ${ }^{73}$ In these cases, international organizations, either as agents or as sets of rules that enhance transparency, appear to have had important effects on information flows and policy transmission.

How might one devise tests for the influence of learning on policy diffusion? There are good reasons to suppose that learning has occurred when we see highly successful policy changes in country A, followed by similar changes in countries $\mathrm{B}$ and $\mathrm{C}$. That is, measurable policy success should increase the probability of adoption elsewhere. In the case of privatization, for example, higher rates of investment and economic growth and lower deficits would suggest that the policy worked at the national level. Over time, the ratio of these measures among privatizers relative to nonprivatizers should predict future privatization efforts. It may be that learning happens at the global level, and it may be that it happens among groups of peers who share information and whose experiences are more relevant to each other-among neighbors, cultural groups, or states at the same level of development. Similar to firms that have sunk investments in particular technologies ${ }^{74}$ governments may be reluctant to change course if the adjustment costs appear high and the payoff uncertain. ${ }^{75}$ Thus, one might expect that governments will change only in the face of strong and compelling evidence.

Learning theories suggest that information about policy success or failure abroad will influence the probability of policy change at home. The information may be acquired rationally, dispassionately, and completely, as in strict Bayesian models. It might be mediated through existing communication networks. Information might flow more quickly among peer groups of countries whose experiences are deemed most relevant to each other. In all cases, however, evidence of success increases the likelihood of adoption elsewhere. As we discuss below, this connection to some

70. See Brooks 2005; Khamfula 1998; and Meseguer 2004.

71. Haas 1959.

72. Quirk 1994.

73. To name but a few: Eising 2002 attributes the spread of liberalization in the electricity sector in Europe to learning facilitated by the Council of the European Union. Nye 1987 found that international institutions reinforced learning with respect to nuclear policy through their use of rules and standard operating procedures. Kahler 1994 has noted that the international financial institutions shape learning to reinforce their policy preferences.

74. See, for example, Atkeson and Kehoe 2001.

75. On the likelihood of incremental change in the absence of a dramatically successful model, see Schneider and Ingram 1988. 
reasonable measure of "success" becomes more tenuous as one moves away from learning and toward diffusion processes based on emulation. ${ }^{76}$

\section{Emulation}

Sociologists have studied policy diffusion through the lens of "social construction" since the late 1970s. ${ }^{77}$ Constructivism is rooted in Weber's insight that to understand social action one must grasp its meaning to the actors, and that that meaning is an empirically traceable product of social context. ${ }^{78}$ The distinguishing feature of social constructivism is its focus on the intersubjectivity of meaningboth legitimate ends and appropriate means are considered social constructs. ${ }^{79}$ According to this view, while policymakers believe that they can, should, and do divine the "best practice" in a given policy area, in fact they cannot accurately judge whether policy A is better than policy B with any certainty. Instead, theory and rhetoric often serve as the basis of decision making. But theory and rhetoric change over time, and as they do, social meaning is constructed and reconstructed. Thus, the same policies can have different meanings over time. Tariffs, for example, were thought to do very different things in 1880, 1947, and 1995.

The "world polity" approach draws on the Weberian view of an increasingly global culture comprising broad consensus on the set of appropriate social actors (individuals, organizations, and nation-states have replaced clans, city-states, fiefdoms), appropriate societal goals (economic growth and social justice have replaced territorial conquest and eternal salvation), and means for achieving those goals (tariff reduction and interest rate manipulation have replaced plunder and incantation). Meyer suggested that a view on what is "appropriate"-in terms of actors, goals, and policy means-has diffused from country to country around the globe, first in the West and then elsewhere. ${ }^{80}$ The initial empirical focus was social policies and human rights. Meyer and colleagues showed that between 1950 and 1970 all countries expanded mass schooling - which had been defined as key to achieving both growth and democracy-regardless of political ideology, political system or level of economic development. ${ }^{81}$ They found that developing and developed countries alike sign human rights treaties to signal their commitment to global norms. Global norms are strong enough to cause even countries that Amnesty International chides for abusing rights to sign on. ${ }^{82}$

76. Many researchers find that learning and emulation are not necessarily mutually exclusive. See, for example, Meseguer 2005.

77. The first sustained analysis appeared in Meyer and Hannan 1979. For reviews of the literature, see Strang and Meyer 1994; Dobbin 1994; Rogers 1995; and Strang and Soule 1998.

78. Weber $1978,4$.

79. See Hirschman 1977; Meyer et al. 1997; and Berger and Luckmann 1966.

80. Boli-Bennett and Meyer 1978.

81. See Meyer et al. 1977; and Meyer, Ramirez, and Soysal 1992.

82. See Boyle and Preves 2000; Forsythe 1991; and Ramirez and McEneaney 1997. 
Social construction became an established paradigm in international relations research in the latter 1990s ${ }^{83}$ For proponents, understanding how public policies become socially accepted is the key to understanding why they diffuse. Social acceptance of a policy approach can happen in several ways. Powerful countries may serve as exemplars. ${ }^{84}$ As we have already pointed out, however, it can be difficult to discern where coercion ends and emulation begins when it comes to the influence of dominant actors.

Two other causal processes seem clearly to fit into the emulation category. First, groups of experts (epistemic communities, discussed above under social learning) may become advocates for a given policy, providing seemingly disinterested and objective analysis of its benefits. Students of epistemic communities postulate that policy professionals, academics, international nongovernmental organizations (INGOs), and NGOs can influence governments to adopt new policies simply by making arguments for them. ${ }^{85}$ Epistemic communities not only help to define new solutions to existing problems (for example, central bank independence as a solution to inflation) but also identify new problems and propose solutions to them (for example, global warming and the Kyoto protocols). The epistemic community of American economists is often seen to have played a critical role in economic liberalization in Latin America and beyond ${ }^{86}$ It may be that Latin American countries sent economics students to the University of Chicago because they wanted, $e x$ ante, to join the liberal bandwagon driven by Friedman and colleagues. This would suggest that North American economists had an effect on Latin American economic policies, but that their influence operated through the preferences of national leaders who sent deputy finance ministers to train in the United States, rather than through the preferences of newly minted Chicago School graduates themselves. Either way, the community of economists has arguably shaped new policy norms.

Whereas conventional logic-of-development arguments suggest that countries will adopt certain programs when they are developmentally ready for them, world polity theorists have found that countries embrace new norms for symbolic reasons, even when they cannot begin to put them into practice. This is particularly true of social welfare policies and human rights. Strang and Chang, for example, find that large numbers of countries ratified International Labor Organization treaties guaranteeing welfare rights, but that only in developed countries did ratification lead to increased welfare expenditures. Developing countries signed the treaty even though they lacked the resources to carry through. This may not represent bad faith so much as the power of new international norms even in countries that are not developmentally capable of implementing them. ${ }^{87}$ Even in the realm of

83. See Finnemore and Sikkink 2001; Ruggie 1998; and Wendt 1999.

84. Haveman 1993.

85. See Haas 1959 and 1992; Mintrom 1997; and Mintrom and Vergari 1998.

86. Numerous studies have purported to show, for example, the influence of "Chicago boys" in economic policy change in Latin America, either directly or indirectly. See Drake 1994; Harberger 1997; Montecinos 1997; and Murillo 2002.

87. Strang and Chang 1993. 
economic policy, countries may adopt new global norms before they are really ready.

The other principal emulation approach draws on reference group theory in social psychology. From this perspective, individuals emulate the behavior of their selfidentified peers, even when they cannot ascertain that doing so will in fact be in their best interests. At the international level, sociocultural linkages (common language, history, religion, and so on) may contribute to "psychological proximity" among nations. ${ }^{88}$ Indeed, many cross-national analyses of diffusion find significant effects of cultural similarities that cannot readily be explained by learning or competition. ${ }^{89}$

A test of these constructivist arguments might begin with a look at the effect of participation in NGOs, INGOs, professional communities, and other groups that actively promote new policy norms. One might also test for the effect of shared cultural values by examining the effect of shared cultural heritage, language, and religion, controlling for effects of competition, learning, and coercion. The availability of good, longitudinal data on a wide range of economic, trade, political, and other factors has made these kinds of nuanced tests of hypotheses possible in recent years. Net of coercion, competition, and learning, do the ideas of leading epistemic communities or advocacy groups have effects? Some of the studies reported in this symposium show that they do.

\section{Four Varieties of Liberalism}

The articles in this symposium explore these four diffusion mechanisms with respect to four different classes of policy: liberalization of international economic transactions (bilateral investment treaties), domestic economic policy liberalization (tax policy), liberalization of the role of government (public-sector downsizing), and political liberalization (democratization). Here we provide a brief policy-by-policy preview.

\section{International Economic Transactions: \\ The Spread of Bilateral Investment Treaties}

Zachary Elkins, Andrew Guzman, and Beth Simmons explore the diffusion of bilateral investment treaties that seek to improve foreign investors' legal redress in countries where local regulatory and legal practices may appear to put foreign investment at risk. The article finds considerable evidence for diffusion through competition. Developing countries are much more likely to sign a bilateral investment treaty (usually with a developed country) when their prime competitors for trade and investment have done so. Other mechanisms may also be at play. Coer- 
cion is not ruled out: countries that draw on the resources of the IMF tend to be much more likely to sign bilateral investment treaties (BITs), which may reflect a degree of pressure to do so. They also find some evidence of learning from the success of other developing country signers: in years when BITs were most strongly associated with FDI inflows, other countries were more likely to sign BITs as well. However, Elkins, Guzman, and Simmons find no evidence of emulation through region, common language or colonial history. They conclude that competitive pressures are likely the strongest engine of diffusion in this area.

\section{Domestic Economic Liberalization: The Diffusion of Tax Schemes Internationally}

Why have governments increasingly implemented domestic policies that seem to favor marketization over governmental intervention? Duane Swank examines the diffusion of new "market-conforming" corporate tax structures in the OECD following the adoption of a new tax regime in the United States in 1986. Swank argues that competition was the major driver of diffusion because the U.S. tax changes were most closely followed in other developed economies with similar political economic structures to those in America-that is, the institutions of liberal (uncoordinated) market institutions. According to Swank, competition with the United States for investment was the driving force of policy change among these countries, but not among the coordinated market economies of northern Europe. These countries came to adopt reforms similar to those enacted by President Ronald Reagan because the United States is the dominant host and supplier of capital investment throughout the developed world. The market for FDI in coordinated market economies, in contrast, operates more independently from the U.S. and is driven by other considerations.

\section{Liberalization of the Structure of Government: The Diffusion of Public-Sector Downsizing}

Chang Kil Lee and David Strang examine public-sector downsizing in the 1980s and 1990s in the OECD. As in the case of "market conforming" tax policies, there is no evidence of coercion. But unlike Swank, Lee and Strang do not believe that competition was the main driver of reductions in public-sector employment. Instead, they focus on an interesting learning process. In the context of the dominance of neoliberal thinking about the efficacy of downsizing, countries took strong signals from evidence that downsizing worked to improve economic performance but heavily discounted evidence showing that bigger public sectors were good for growth (by providing collective goods such as education and infrastructure undersupplied by markets). Lee and Chang thus propose a hybrid emulation and learning dynamic in which an influential epistemic community defined downsizing as a solution to the problem of poor economic performance, which in turn catalyzed only one type of learning - countries ignored evidence that was inconsistent with the new received wisdom but acted on evidence that was consistent with it. 


\section{Political Liberalization: The International Spread of Democracy}

The final article examines political liberalization. Kristian Gleditsch and Michael Ward examine the diffusion of democracy and begin with the observation that the process of democratization has been geographically clustered. Given that most of the domestic correlates of democracy (levels of income, education, and so on) tend to change slowly, there is a strong prima facie case to be made that democracy spreads by some sort of regional diffusion. What is the nature of the diffusion? Gleditsch and Ward contend that coercion is the most important driver of this dynamic, though in a way that is quite different from the core-periphery archetype. In the case of democratization, powerful prodemocracy groups in neighboring countries apparently represent an effective power resource for would-be democratizers. Conversely, civil conflict in neighboring countries reduces the capacity of democratizers elsewhere in the region. Power operates here, but it is localized power resources available to pro- and antidemocracy groups within nations that matter.

\section{Conclusion}

How is it that we have come to live in such a globalized world? This is one of the most fundamental and puzzling questions we can ask as social scientists examining political and economic policy developments over the past half-century. How did marketization in its various guises gain a significant foothold in a growing number of countries? How and why have the various trappings of political liberalization - from elections to human rights-become important governing principles in most (though certainly not all) regions of the world?

Coercion, competition, learning, and emulation are distinct_and we think powerful-concepts. ${ }^{90}$ Nonetheless, drawing sharp dividing lines becomes more difficult as we move into the interstices among them. The IMF's support for liberalization can be understood as coercive when policy conditions are explicitly attached to loans. But it may also be the case that the ideas espoused by the Fund and other international financial institutions are followed not only because of asymmetries in power but also for the kinds of reasons that constructivists focus on with respect to emulation. Distinctions might also be difficult to draw in the abstract between channeled learning and emulation. After all, as learning becomes more "boundedly" rational, it inevitably drifts closer to the kinds of processes one normally associates with emulation-taking cues from other countries with which a given nation shares cultural, linguistic, historical or religious affinities. The authors recognize the ambiguities that remain, despite state-of-the-art empirical testing.

90. For a recent argument that these (and possibly other) diffusion mechanisms can in fact all be subsumed within a single theoretical framework, see Braun and Gilardi 2006. 
Each article contributes to a more qualitative interpretation of the results in light of the context of the issue area. Taken as a whole, these articles make a significant contribution to understanding liberalization's diffusion throughout much of the world over the second half of the twentieth century.

The articles that follow provide a fascinating set of windows on the fundamental processes underlying globalization. No one denies that the underlying processes are complex, but our strategy in this volume is to contribute to knowledge of a complex whole through well-defined and rigorously executed studies that engage the basic framework set out in this introduction. This introduction is of course only a starting point for the inquiries that follow. Each piece adds its own rich insights to the issue area, adapting and amending the mechanisms set out above in appropriate and creative ways.

While each substantive article has its creative take on diffusion, all of the contributing scholars have pooled their intellectual efforts by working through a fairly consistent set of alternative mechanisms as well as testing for the "null hypothesis" of independent decision making. Swank's article on tax liberalization covers important domestic political and economic explanations (the political orientation of the government, for example) that could be independently responsible for a more market-friendly tax policy, and controls for trade competition, as well as other diffusion mechanisms. The Elkins, Simmons, and Guzman article on bilateral trade agreements explicitly controls for the influences of liberalization in the region as well as liberalization trends in those states most likely to compete for global capital. The willingness of these authors to engage several common alternative hypotheses elucidates the diffusion of policies that have enhanced the global flow of capital over the past several decades.

Finally, the article on political liberalization presents strikingly complementary findings. Gleditsch and Ward's work on the diffusion of democracy gives the null hypothesis (independent national factors) a real fighting chance, taking on "social requisites" theory. They find that the essentially domestic explanation is not quite as convincing as various diffusion influences on the prospects of political liberalization. To be sure, their explanations differ greatly: Gleditsch and Ward concentrate on the political resources provided by democratizing neighbors.

Very few symposia address as broad a topic in as comprehensive a way as does this collection of articles. All of the contributions address "liberalization," but additional insights are gleaned by comparing marketization with democratization. Both may have their ideational explanations, but marketization, these studies seem to suggest, tends also to be subject to stronger competitive factors that are not as clearly present in explaining democratization. It is interesting to note that among the economic policy topics, competitive pressures can be found not only for external liberalization, but for domestic policy changes as well. This suggests that political economy explanations should begin seriously to resituate the study of domestic institutions and politics in a broader global or at least regional framework. Finally, this collection of articles allows for some interesting comparisons of global processes with regional ones. Two articles-those by Swank and Lee and Strang-focus exclusively on the OECD countries. These regional articles are 
quite telling in the context of the broader project. Swank's article, for example, highlights the robustness of competitive pressures, which seem to be at work within the OECD as well as globally (as Elkins, Guzman, and Simmons demonstrate). The article by Lee and Strang shows that particular ideas account (asymmetrically) for much policy diffusion.

The goal of this volume is to theorize and test explanations of policy liberalization that involve interdependent decision making among governments. Large clusters of scholarship have tended, in our view, to be too domestic in orientation. The interdisciplinary nature of this project has been helpful in this regard. Not only is it useful for "political economy" approaches to liberalization to become resituated in a politically dynamic international economy; it is also useful to understand the nature of the international setting itself. Collaboration between political scientists and sociologists has usefully exposed areas of overlap as well as challenged scholars to think about how to incorporate and test alternative explanations from other disciplinary traditions. The articles that follow represent our efforts to understand, confront, and test explanations that seem promising without undue deference to disciplinary boundaries.

\section{References}

Atkeson, Andrew, and Patrick J. Kehoe. 2001. The Transition to a New Economy after the Second Industrial Revolution. NBER Working Paper 8676. Cambridge, Mass.: National Bureau of Economic Research.

Axelrod, Robert. 1997. The Dissemination of Culture: A Model with Local Convergence and Global Polarization. Journal of Conflict Resolution 41 (2):203-26.

Baldwin, Richard E, and Paul Krugman. 2004. Agglomeration, Integration and Tax Harmonisation. European Economic Review 48 (1):1-23.

Banerjee, Abhijit V. 1992. A Simple Model of Herd Behavior. Quarterly Journal of Economics 107 (3):797-817.

Beck, Nathaniel, Kristian S. Gleditsch, and Kyle Beardsley. 2006. Space Is More Than Geography: Using Spatial Econometrics in the Study of Political Economy. International Studies Quarterly 50 (1):27-44.

Berger, Peter, and Thomas Luckmann. 1966. The Social Construction of Reality: A Treatise on the Sociology of Knowledge. Garden City, N.Y.: Doubleday.

Bernhard, William, and David Leblang. 2002. Political Parties and Monetary Commitments. International Organization 56 (4):803-30.

Berry, Frances Stokes, and William D. Berry. 1990. State Lottery Adoptions as Policy Innovations: An Event History Analysis. American Political Science Review 84 (2):322-29.

Bikhchandani, Sushil, David Hirshleifer, and Ivo Welch. 1992. A Theory of Fads, Fashion, Custom, and Cultural Change as Informational Cascades. Journal of Political Economy 100 (5):992-1026.

Boli-Bennett, John, and John W. Meyer. 1978. The Ideology of Childhood and the State: Rules Distinguishing Children in National Constitutions, 1870-1970. American Sociological Review 43 (6):797-812.

Boyle, Elizabeth Heger, and Sharon E. Preves. 2000. National Politics as International Process: The Case of Anti-Female-Genital-Cutting Laws. Law \& Society Review 34 (3):703-37.

Braun, Dietmar, and Fabrizio Gilardi. Forthcoming. Taking "Galton's Problem" Seriously: Towards a Theory of Policy Diffusion. Journal of Theoretical Politics 18 (3):298-322.

Brooks, Sarah M. 2005. Interdependent and Domestic Foundations of Policy Change: The Diffusion of Pension Privatization Around the World. International Studies Quarterly 49 (2):273-94. 
Broz, J. Lawrence. 2002. Political System Transparency and Monetary Commitment Regimes. International Organization 56 (4):861-87.

Brueckner, Jan K. 2000. Welfare Reform and the Race to the Bottom: Theory and Evidence. Southern Economic Journal 66 (3):505-25.

Brune, Nancy, Geoffrey Garrett, and Bruce Kogut. 2004. The International Monetary Fund and the Global Spread of Privatization. IMF Staff Papers 51 (2):195-219.

Cai, Hongbin, and Daniel Treisman. 2004. State Corroding Federalism. Journal of Public Economics $88(3-4): 819-43$.

Clark, William R. 2002. Partisan and Electoral Motivations and the Choice of Monetary Institutions under Fully Mobile Capital. International Organization 56 (4):725-49.

Coleman, James S., Elihu Katz, Herbert Menzel, and Columbia University Bureau of Applied Social Research. 1966. Medical Innovation: A Diffusion Study. Indianapolis, Ind.: Bobbs-Merrill Co.

Collier, Ruth Berins. 1999. Paths Toward Democracy: The Working Class and Elites in Western Europe and South America. New York: Cambridge University Press.

Cordella, Tito, and Giovanni Dell'Ariccia. 2002. Limits of Conditionality in Poverty Reduction Programs. IMF Staff Papers 49 (Special Issue):68-86.

Daley, Dorothy M., and James C. Garand. 2005. Horizontal Diffusion, Vertical Diffusion, and Internal Pressure in State Environmental Policymaking, 1989-1998. American Politics Research 33 (5):615-44.

Dobbin, Frank. 1994. Forging Industrial Policy: The United States, Britain, and France in the Railway Age. New York: Cambridge University Press.

Dobson, Wendy, and Gary C. Hufbauer. 2001. World Capital Markets: Challenge to the G-10. Washington, D.C.: Institute for International Economics.

Doyle, Michael W. 1986. Liberalism and World Politics. American Political Science Review 80 (4):1151-69.

Drake, Paul W., ed. 1994. Money Doctors, Foreign Debts, and Economic Reforms in Latin America from the 1890s to the Present. Wilmington, Del.: SR Books.

Drazen, Allan. 2002. Conditionality and Ownership in IMF Lending: A Political Economy Approach. IMF Staff Papers 49 (0):36-67.

Edwards, Sebastian. 1997. Trade Liberalization Reforms and the World Bank. American Economic Review 87 (2):43-48.

Eichengreen, Barry, and Christof Ruehl. 2000. The Bail-in Problem: Systemic Goals, Ad Hoc Means. NBER Working Paper 7653. Cambridge, Mass.: National Bureau of Economic Research.

Eising, Rainer. 2002. Policy Learning in Embedded Negotiations: Explaining EU Electricity Liberalization. International Organization 56 (1):85-120.

Elkins, Zachary, and Beth Simmons. 2005. On Waves, Clusters, and Diffusion: A Conceptual Framework. Annals of the American Academy of Political and Social Science 598 (1):33-51.

Elkins, Zachary, Andrew T. Guzman, and Beth Simmons. 2006. Competing for Capital: The Diffusion of Bilateral Investment Treaties 1960-2000. International Organization 60 (4):811-46.

Epstein, Gerald A., and Juliet B. Schor. 1992. Structural Determinants and Economic Effects of Capital Controls in OECD Countries. In Financial Openness and National Autonomy: Opportunities and Constraints, edited by Tariq Banuri and Juliet Schor, 136-161. Oxford, England: Clarendon Press.

Finnemore, Martha, and Kathryn Sikkink. 2001. Taking Stock: The Constructivist Research Program in International Relations and Comparative Politics. Annual Review of Political Science 4 (1):391-416.

Forsythe, David P. 1991. The Internationalization of Human Rights. Lexington, Mass.: Lexington Books.

Frieden, Jeffry A. 1991. Invested Interests: The Politics of National Economic Policies in a World of Global Finance. International Organization 45 (4):425-51.

Frieden, Jeffry A., and Ronald Rogowski. 1996. The Impact of the International Economy on National Policies: An Analytical Overview. In Internationalization and domestic politics, edited by R.O. Keohane and H.V. Milner. Cambridge [England]; New York, N.Y., USA: Cambridge University Press.

Gale, Douglas, and Shachar Kariv. 2003. Bayesian Learning in Social Networks. Games and Economic Behavior 45 (2):329-46.

Garrett, Geoffrey. 1998. Global Markets and National Politics: Collision Course or Virtuous Circle? International Organization 52 (4):787-824. 
Garrett, Geoffrey. 2001. Globalization and Government Spending Around the World. Studies in Comparative International Development 35 (4):3-29.

Garrett, Geoffrey, and Peter Lange. 1995. Internationalization, Institutions, and Political Change. International Organization 49 (4):627-55.

Garrett, Geoffrey, and Deborah Mitchell. 2001. Globalization, Government Spending and Taxation in the OECD. European Journal of Political Research 39 (2):145-77.

Garrett, Geoffrey, and Barry R. Weingast. 1993. Ideas, Interests, and Institutions: Constructing the European Community's Internal Market. In Ideas and Foreign Policy: Beliefs, Institutions, and Political Change, edited by Judith Goldstein and Robert Keohane, 173-206. Ithaca, N.Y.: Cornell University Press.

Gastanaga, Victor M., Jeffrey B. Nugent, and Bistra Pashamova. 1998. Host Country Reforms and FDI Inflows: How Much Difference Do They Make? World Development 26 (7):1299-314.

Genschel, Philipp. 2002. Globalization, Tax Competition, and the Welfare State. Politics and Society 30 (2):245-75.

Gilardi, Fabrizio. 2005. The Institutional Foundations of Regulatory Capitalism: The Diffusion of Independent Regulatory Agencies in Western Europe. Annals of the American Academy of Political and Social Science 598 (1):84-101.

Giovannini, Alberto, and Martha De Melo. 1993. Government Revenue from Financial Repression. American Economic Review 83 (4):953-63.

Goolsbee, Austan, and Peter J. Klenow. 1999. Evidence on Learning and Network Externalities in the Diffusion of Home Computers. NBER Working Paper 7329. Cambridge, Mass.: National Bureau of Economic Research.

Gould, Erica R. 2003. Money Talks: Supplementary Financiers and International Monetary Fund Conditionality. International Organization 57 (3):551-86.

Gourevitch, Peter Alexis. 1986. Politics in Hard Times: Comparative Responses to International Economic Crises. Ithaca, N.Y.: Cornell University Press.

Gray, Virginia. 1973. Innovation in the States: A Diffusion Study. American Political Science Review 67 (4):1174-85.

—_ 1994. Competition, Emulation, and Policy Innovation. In New Perspectives on American Politics, edited by Lawrence C. Dodd and Calvin C. Jillson, 230-48. Washington, D.C.: CQ Press.

Grilli, Vittorio, and Gian Maria Milesi-Ferretti. 1995. Economic Effects and Structural Determinants of Capital Controls. IMF Staff Papers 42 (3):517-51.

Gruber, Lloyd. 2000. Ruling the World: Power Politics and the Rise of Supranational Institutions. Princeton, N.J.: Princeton University Press.

Haas, Ernst B. 1980. Why Collaborate? Issue-Linkage and International Regimes. World Politics 32 (3):357-405.

1959. The Future of West European Political and Economic Unity. Santa Barbara, Calif.: Technical Military Planning Operation, General Electric Company.

Haas, Peter M. 1992. Introduction: Epistemic Communities and International Policy Coordination. International Organization 46 (1):1-35.

Hall, Peter A., ed. 1989. The Political Power of Economic Ideas: Keynesianism across Nations. Princeton, N.J.: Princeton University Press.

Hallerberg, Mark. 2002. Veto Players and the Choice of Monetary Institutions. International Organization 56 (4):775-802.

Harberger, Arnold C. 1997. Good Economics Comes to Latin America, 1955-1995. History of Political Economy 28 (0):301-11.

Haveman, Heather A. 1993. Follow the Leader: Mimetic Isomorphism and Entry into New Markets. Administrative Science Quarterly 38 (4):593-627.

Heichel, Stephan, Jessica Pape, and Thomas Sommerer. 2005. Is There Convergence in Convergence Research? An Overview of Empirical Studies on Policy Convergence. Journal of European Public Policy 12 (5):817-40.

Henisz, Witold J. 2000. The Institutional Environment for Multinational Investment. Journal of Law, Economics, and Organization 16 (2):334-64. 
Hira, Anil. 1998. Ideas and Economic Policy in Latin America: Regional, National, and Organizational Case Studies. Westport, Conn.: Praeger.

Hirschman, Albert O. 1977. The Passions and the Interests: Political Arguments for Capitalism Before Its Triumph. Princeton, N.J.: Princeton University Press.

Huntington, Samuel P. 1991. The Third Wave: Democratization in the Late Twentieth Century. Norman: University of Oklahoma Press.

Jensen, Nathan M. 2003. Democratic Governance and Multinational Corporations: Political Regimes and Inflows of Foreign Direct Investment. International Organization 57 (3):587-616.

Kahler, Miles. 1994. External Influence, Conditionality, and the Politics of Adjustment. In Voting for Reform: Democracy, Political Liberalization, and Economic Adjustment, edited by Stephan Haggard and Steven Benjamin Webb, 89-136. New York: World Bank/Oxford University Press.

- 1992. External Influence, Conditionality, and the Politics of Adjustment. In The Politics of Economic Adjustment: International Constraints, Distributive Conflicts, and the State, edited by Stephan Haggard and Robert R. Kaufman, 89-136. New York: World Bank/Oxford University Press.

Kahneman, Daniel, Paul Slovic, and Amos Tversky, eds. 1982. Judgment Under Uncertainty: Heuristics and Biases. New York: Cambridge University Press.

Kaminsky, Graciela L., and Carmen M. Reinhart. 2000. On Crises, Contagion, and Confusion. Journal of International Economics 51 (1):145-68.

Kaplinsky, Raphael. 2001. Globalisation and Economic Security. IDS Bulletin 32 (2):13-24.

Kaufman, Robert R., and Alex Segura-Ubiergo. 2001. Globalization, Domestic Politics, and Social Spending in Latin America: A Time-Series Cross-Section Analysis, 1973-1997. World Politics 53 (4):553-87.

Keefer, Philip, and David Stasavage. 2002. Checks and Balances, Private Information, and the Credibility of Monetary Commitments. International Organization 56 (4):751-74.

Keller, Wolfgang. 2002. Geographic Localization of International Technology Diffusion. American Economic Review 92 (1):120-42.

Keohane, Robert O., and Helen V. Milner, eds. 1996. Internationalization and domestic politics, Cambridge Studies in Comparative Politics. Cambridge; New York: Cambridge University Press.

Khamfula, Yohane. 1998. Influence of Social Learning on Exchange Rate Policy in Developing Countries: A Preliminary Finding. Applied Economics 30 (5):697-704.

Knill, Christoph. 2005. Introduction: Cross-National Policy Convergence: Concepts, Approaches and Explanatory Factors. Journal of European Public Policy 12 (5):764-74.

Lake, David A., and Robert Powell. 1999. Strategic choice and International Relations. Princeton, N.J.: Princeton University Press.

Lenschow, Andrea, Duncan Liefferink, and Sietske Veenman. 2005. When the Birds Sing. A Framework for Analysing Domestic Factors Behind Policy Convergence. Journal of European Public Policy 12 (5):797-816.

Levy, Jack S. 1994. Learning and Foreign Policy: Sweeping a Conceptual Minefield. International Organization 48 (2):279-312.

Li, Richard P. Y., and William R. Thompson. 1975. The 'Coup Contagion' Hypothesis. Journal of Conflict Resolution 19 (1):63-88.

Linz, Juan J., and Alfred C. Stepan. 1996. Problems of Democratic Transition and Consolidation : Southern Europe, South America, and Post-Communist Europe. Baltimore, Md.: Johns Hopkins University Press.

Lutz, James M. 1987. Regional Leadership Patterns in the Diffusion of Public Policies. American Politics Quarterly 15 (3):387-98.

Malinowski, Bronislaw. 1944. A Scientific Theory of Culture. Chapel Hill: University of North Carolina Press.

March, James, and Herbert Simon. 1993. Organizations. Second ed. Cambridge, Mass.: David Blackwell.

Markoff, John. 1996. Waves of Democracy: Social Movements and Political Change. Thousand Oaks, Calif.: Pine Forge Press.

McNamara, Kathleen R. 1998. The Currency of Ideas: Monetary Politics in the European Union. Ithaca, N.Y.: Cornell University Press. 
Meseguer, Covadonga. 2004. What Role for Learning? The Diffusion of Privatisation in OECD and Latin American Countries. Journal of Public Policy 24 (3):299-325.

. 2005. Policy Learning, Policy Diffusion, and the Making of a New Order. The Annals of the American Academy of Political and Social Science 598 (1):67-82.

Meyer, John W., John Boli, George M. Thomas, and Francisco O. Ramirez. 1997. World Society and the Nation-State. American Journal of Sociology 103 (1):144-81.

Meyer, John W., and Michael T. Hannan. 1979. National Development and the World System: Educational, Economic, and Political Change, 1950-1970. Chicago: University of Chicago Press.

Meyer, John W., Francisco O. Ramirez, Richard Rubinson, and John Boli-Bennett. 1977. The World Educational Revolution, 1950-1970. Sociology of Education 50 (4):242-58.

Meyer, John W., Francisco O. Ramirez, and Yasmine N. Soysal. 1992. World Expansion of Mass Education, 1870-1980. Sociology of Education 65 (2):128-49.

Meyer, William H. 1998. Human Rights and International Political Economy in Third World Nations: Multinational Corporations, Foreign Aid, and Repression. Westport, Conn.: Praeger.

Mintrom, Michael. 1997. Policy Entrepreneurs and the Diffusion of Innovation. American Journal of Political Science 41 (3):738-70.

Mintrom, Michael, and Sandra Vergari. 1998. Policy Networks and Innovation Diffusion: The Case of State Education Reforms. Journal of Politics 60 (1):126-48.

Montecinos, Verónica. 1997. Economists in Political and Policy Elites in Latin America. In The Post1945 Internationalization of Economics, edited by A. W. Coats, 279-300. Durham, N.C.: Duke University Press.

Mosley, Layna. 2003. Global Capital and National Governments. New York: Cambridge University Press.

Murillo, M. Victoria. 2002. Political Bias in Policy Convergence: Privatization Choices in Latin America. World Politics 54 (4):462-93.

Neumayer, Eric, and Indra de Soysa. 2006. Globalization and the Right to Free Association and Collective Bargaining: An Empirical Analysis. World Development 34 (1):31-49.

Nye, Joseph S., Jr. 1987. Nuclear Learning and U.S.-Soviet Nuclear Regimes. International Organization 41 (3):371-402.

Oates, Wallace E. 2001. Fiscal Competition or Harmonization? Some Reflections. National Tax Journal 54 (3):507-12.

O’Donnell, Guillermo A., Philippe C. Schmitter, and Laurence Whitehead, eds. 1986. Transitions from Authoritarian Rule. Baltimore, Md.: Johns Hopkins University Press.

O’Loughlin, John, Michael D. Ward, Corey L. Lofdahl, Jordin S. Cohen, David S. Brown, David Reilly, Kristian S. Gleditsch, and Michael Shin. 1998. The Diffusion of Democracy, 1946-1994. Annals of the Association of American Geographers 88 (4):545-74.

Peterson, Paul E., and Mark C. Rom. 1990. Welfare Magnets: A New Case for a National Standard. Washington, D.C.: Brookings Institution.

Polak, Jacques J. 1997. The Contribution of the International Monetary Fund. In The Post-1945 Internationalization of Economics, edited by A. W. Coats, 211-24. Durham, N.C.: Duke University Press.

Powell, Walter W. 1990. Neither Market nor Hierarchy: Network Forms of Organization. In Research in Organizational Behavior 12, edited by L. L. Cummings and B. Shaw, 295-336. Greenwich, Conn.: JAI Press.

Prasad, Eswar, Kenneth Rogoff, Shang-Jin Wei, and M. Ayhan Kose. 2003. Effects of Financial Globalization on Developing Countries: Some Empirical Evidence. Available at 〈http://www.imf.org/ external/np/res/docs/2003/031703.pdf). Accessed June 30, 2006.

Przeworski, Adam, Michael E. Alvarez, Jose Antonio Cheibub, and Fernando Limongi. 2000. Democracy and Development: Political Institutions and Well-Being in the World, 1950-1990. Cambridge: Cambridge University Press.

Quinn, Dennis P., and Carla Inclán. 1997. The Origins of Financial Openness: A Study of Current and Capital Account Liberalization. American Journal of Political Science 41 (3):771-813.

Quirk, Peter J. 1994. Adopting Currency Convertibility: Experiences and Monetary Policy Considerations for Advanced Developing Countries. IMF Working Paper 94/96. Washington, D.C.: International Monetary Fund. 
Ramirez, Francisco O., and Elizabeth H. McEneaney. 1997. From Women's Suffrage to Reproduction Rights? Cross-National Comparisons. International Journal of Comparative Sociology 38 (1-2):6-24.

Rodrik, Dani. 1997. Has Globalization Gone Too Far? Washington, D.C.: Institute for International Economics.

Rogers, Everett M. 1995. Diffusion of Innovations. New York: Free Press.

Rogowski, Ronald. 1989. Commerce and Coalitions: How Trade Affects Domestic Political Alignments. Princeton, N.J.: Princeton University Press.

Rose, Richard. 1993. Lesson-Drawing in Public Policy: A Guide to Learning across Time and Space. Chatham, N.J.: Chatham House.

Rudra, Nita. 2002. Globalization and the Decline of the Welfare State in Less-Developed Countries. International Organization 56 (2):411-45.

Ruggie, John Gerard. 1998. What Makes the World Hang Together? Neo-Utilitarianism and the Social Constructivist Challenge. International Organization 52 (4):855-85.

Sachs, Jeffrey, and Harry Huizinga. 1987. U.S. Commercial Banks and the Developing-Country Debt Crisis. Brookings Papers on Economic Activity (2):555-606.

Sanahuja, Jose Antonio. 2000. Trade, Politics, and Democratization: The 1997 Global Agreement between the European Union and Mexico. Journal of Interamerican Studies and World Affairs 42 (2):35-62.

Schelling, Thomas C. 1960. The Strategy of Conflict. Cambridge, Mass.: Harvard University Press.

Schneider, A., and H. Ingram. 1988. Systematically 'Pinching' Ideas: A Comparative Approach to Policy Design. Journal of Public Policy 8 (1):61-80.

Simmons, Beth A. 2001. The International Politics of Harmonization: The Case of Capital Market Regulation. International Organization 55 (3):589-620.

Simmons, Beth A., and Zachary Elkins. 2004. The Globalization of Liberalization: Policy Diffusion in the International Political Economy. American Political Science Review 98 (1):171-89.

Sinn, Hans-Werner, and Wolfgang Ochel. 2003. Social Union, Convergence and Migration. Journal of Common Market Studies 41 (5):869-96.

Starr, Harvey. 1991. Democratic Dominoes: Diffusion Approaches to the Spread of Democracy in the International System. Journal of Conflict Resolution 35 (2):356-81.

Strang, David, and Patricia Mei Yin Chang. 1993. The International Labor Organization and the Welfare State: Institutional Effects on National Welfare Spending, 1960-80. International Organization 47 (2):235-62.

Strang, David, and John W. Meyer. 1994. Institutional Conditions for Diffusion in Institutional Environments and Organization: Structural Complexity and Individualism, edited by W. Richard Scott and John W. Meyer, 100-12. Thousand Oaks, Calif.: Sage.

Strang, David, and Sarah A. Soule. 1998. Diffusion in Organizations and Social Movements: From Hybrid Corn to Poison Pills. Annual Review of Sociology 24:265-90.

Swank, Duane. 1992. Politics and the Structural Dependence of the State in Democratic Capitalist Nations. American Political Science Review 86 (1):38-54.

1998. Funding the Welfare State: Globalization and the Taxation of Business in Advanced Market Economies. Political Studies 46 (4):671-92.

Thomas, George M., John W. Meyer, Francisco O. Ramirez, and John Boli. 1987. Institutional Structure: Constituting State, Society, and the Individual. Newbury Park, Calif.: Sage Publications.

Vreeland, James Raymond. 2003. The IMF and Economic Development. New York: Cambridge University Press.

de Vries, Barend A. 1997. The World Bank as an International Player in Economic Analysis. In The Post-1945 Internationalization of Economics, edited by A. W. Coats, 225-44. Durham, N.C.: Duke University Press.

Weber, Max. 1978. Economy and Society. Two Volumes. Edited by Guenther Roth and Claus Wittich. Berkeley: University of California Press.

Wendt, Alexander. 1999. Social Theory of International Politics. Cambridge: Cambridge University Press. Williamson, John. 1993. Democracy and the 'Washington Consensus.' World Sevelopment 21 (8):132936. 